\title{
Fatty acid profile in vertical strata of elephant grass subjected to intermittent stocking
}

\author{
KAMILA M. DIAS ${ }^{1}$, DANIEL SCHMITT ${ }^{1}$, GISELLE R. RODOLFO ${ }^{1}$, FRANCISCO C. DESCHAMPS $^{2}$, \\ GUILHERME N. CAMARGO ${ }^{1}$, RAPHAEL S. PEREIRA ${ }^{1}$ and ANDRÉ F. SBRISSIA ${ }^{1}$
}

\author{
${ }^{1}$ Departamento de Produção Animal e Alimentos, Universidade do Estado de Santa \\ Catarina/UDESC, Av. Camões, 2090, 88520-000 Lages, SC, Brazil \\ ${ }^{2}$ Empresa de Pesquisa Agropecuária e Extensão Rural de Santa Catarina/EPAGRI, Rodovia \\ Antônio Heil, 6800, Caixa Postal 277, 88112-318 Itajaí, SC, Brazil
}

Manuscript received on April 13, 2015; accepted for publication on August 31, 2015

\begin{abstract}
The milk and meat from animals with a pasture-based diet have higher proportions of CLA and C18:3 and lower omega-6:omega-3 ratios than products from animals with diets based on corn silage and concentrate. However, most of the published studies have evaluated fatty acid profiles in temperate climate grasses and the literature with tropical grasses is scarce. Thus, the aim of this study was to evaluate the morphological and fatty acid compositions in the vertical strata of elephant grass (Pennisetum purpureum Schum.) swards subjected to grazing heights ( 90 or $120 \mathrm{~cm}$ pre-grazing heights) and levels of defoliation $(50 \%$ or $70 \%$ removal of the initial pre-grazing height). There were no interactions among pre-grazing height, the level of defoliation and grazing stratum. However, higher proportion of $\mathrm{C} 18: 3(58 \%$ and $63 \%)$ was found in the $90-\mathrm{cm}$ swards and in the half upper stratum. A higher proportion of $\mathrm{C} 18: 3$ was associated with a higher leaf proportion and crude protein content. Thus, the upper stratum of sward or a grazing management scheme (e.g. first-last stocking) resulting in a higher proportion of leaves and crude protein both provide higher proportions of $\mathrm{C} 18: 3$ to animals grazing in elephant grass swards.
\end{abstract}

Key words: Linolenic acid, Pennisetum purpureum Schum, Polyunsaturated fatty acid, Tropical forage.

\section{INTRODUCTION}

In recent decades, the scientific community has reported that food containing high proportions of saturated fatty acids (SFAs) and cholesterol is associated with an increased risk of cardiovascular disease, which has generated concern regarding the consumption of saturated fat, including milk, meat and eggs (Putnam et al. 2002, O'Keeffe and

Correspondence to: André Fischer Sbrissia

E-mail: sbrissia@cav.udesc.br
St-Onge 2013). However, recent research suggests that not all SFAs have negative effects on human health (Daley et al. 2010), and ruminant milk and meat contain some polyunsaturated fatty acids (PUFAs) that have beneficial effects (Demeyer and Doreau 1999). Among PUFAs, those with higher proportions of C18:2 cis-9 trans-11 (conjugated linolenic acid: CLA) and omega-6:omega-3 ratios $<4: 1$ appear to reduce the risks of cardiovascular disease, hyperglycaemia and cancer (Mcguire and Mcguire 2000). 
Ruminant milk and meat are sources of CLA and omega-3 fatty acids in the human diet, and the concentration of these nutrients in ruminant products is mainly related to the proportions of $\mathrm{C} 18: 2$ and C18:3 in animal feed and the incomplete ruminal biohydrogenation of these molecules (Bauman et al. 2000, Lock and Garnsworthy 2002). As C18:3 is the most common fatty acid (FA) in forage plants, the use of pasture as the main or exclusive source of animal feed provides a sustainable source of PUFAs (Palladino et al. 2009). Milk and meat from animals with a pasture-based diet have higher proportions of CLA and C18:3 and lower omega6:omega-3 ratios than products from animals with diets based on corn silage and concentrate (Revello et al. 2010).

The concentrations of $\mathrm{C} 18: 2$ and $\mathrm{C} 18: 3$ in forage plants can change according to plant species (Clapham et al. 2005, Dierking et al. 2010), leaf senescence (Thomas 1986), growth stage (Boufaïed et al. 2003), conservation method (Elgersma et al. 2003), incidence of solar radiation and nitrogen (N) fertilisation (Witkowska et al. 2008). However, many of the published studies have evaluated fatty acid profiles in temperate climate grasses with forage samples that did not represent the potential grazed stratum. Thus, the aim of this study was to evaluate the morphological and fatty acid compositions in the vertical strata of elephant grass swards (Pennisetum purpureum Schum. cv. Pioneiro) subjected to different grazing heights and levels of defoliation.

\section{MATERIALS AND METHODS}

The experiment was carried out from February to June 2011 at Dairy Cattle Farming Sector, Santa Catarina State University (UDESC), Lages, SC, Brazil (27\%48'58" S and 50¹9'34"W; and 884 asl) on a elephant grass pasture (Pennisetum purpureum Schum. cv. Pioneiro) established in 2010 and was approved by the Ethics Commitee for Animal Experimentation of UDESC (protocol 1.41.11). The climate is humid subtropical with cool summers and no dry season; the mean annual temperature is $15.8^{\circ} \mathrm{C}$, and the mean annual precipitation is $1552 \mathrm{~mm}$. Weather data for the study period are presented in Fig. 1 (EPAGRI 2012).

The experimental design was a randomised complete block with a $2 \times 2$ factorial arrangement
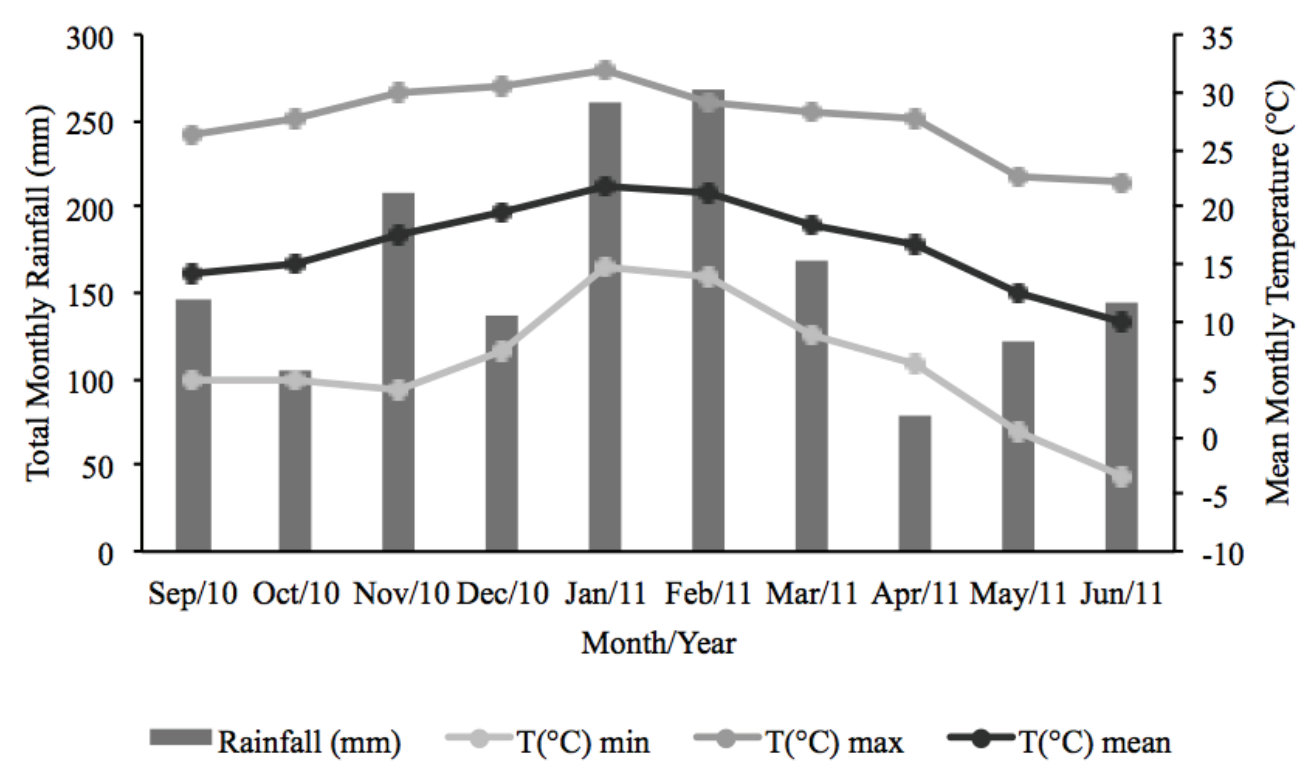

Figure 1 - Total monthly rainfall during the experimental period and mean monthly temperature from 1925 to 2011. 
design and three replications. Treatments were combinations of two pre-grazing heights (90 or 120 $\mathrm{cm}$ ) and two levels of defoliation intensity (50 or $70 \%$ removal of the sward height before grazing). Hereafter, the four treatments are designated 90/50, 90/70, 120/50, and 120/70.

The choice of a pre-grazing height of $90 \mathrm{~cm}$ was based on data from two other elephant grass cultivars, Cameroon and Napier, that also have a large leaf mass at heights of 100 and $85 \mathrm{~cm}$, respectively (Voltolini et al. 2010, Pereira et al. 2014). The height of $120 \mathrm{~cm}$ was chosen to test pasture management that promotes taller sward, such as that commonly used by local farmers, which generally results in a lower proportion of leaves and a higher proportion of stems and dead material. The levels of defoliation were chosen to compare the FA profile in forage mostly associated with higher leaf mass $(50 \%)$ with the FA profile of forage in which animals remove a higher proportion of mass (higher grazing efficiency; 70\%).

The total experimental area was approximately $0.8 \mathrm{ha}$, and it was divided into three blocks with four paddocks of approximately $560 \mathrm{~m}^{2}$ each, in addition to an adjacent area of $800 \mathrm{~m}^{2}$ used for animal adaptation and rest. Fertilisation with $50 \mathrm{~kg}$ of $\mathrm{N} \mathrm{ha}^{-1}$ (as urea) was applied to the overall area before the beginning of the experiment. During the experimental period, nitrogen was always applied to each paddock after grazing at a rate of $2 \mathrm{~kg}$ of $\mathrm{N} / \mathrm{ha}$ /day based on the time needed for regrowth between the previous and current cycle. The aim of this strategy was to provide a similar amount of $\mathrm{N}$ for the same regrowth period for all treatments.

The average pre- and post-grazing heights were measured using a "sward stick" (Barthram 1985) in a "zig-zag" pattern at 60 randomly selected points in each paddock. Sward height was measured from ground level to the top of the leaf horizon. The first grazing cycle was only used to adapt the sward and to intentionally create residues (post-grazing heights targets). Therefore sampling was conducted
TABLE I

Portion of the canopy height represented in various strata for the four grazing treatments.

\begin{tabular}{cccc}
\hline \multirow{2}{*}{ Treatment } & \multicolumn{3}{c}{ Sward height (cm) } \\
\cline { 2 - 4 } & Stratum 1 & Stratum 2 & Residue \\
$90 / 50$ & 90 to 67 & 67 to 45 & 45 to ground level \\
$90 / 70$ & 90 to 59 & 59 to 27 & 27 to ground level \\
$120 / 50$ & 120 to 90 & 90 to 60 & 60 to ground level \\
$120 / 70$ & 120 to 78 & 78 to 36 & 36 to ground level \\
\hline
\end{tabular}

during the second and third grazing cycles (encompassing two seasons of the year: summer and autumn) between February and June 2011. Evaluations were performed during the summer/ autumn period as from June to September it is very common the occurrence of frosts (the experiment was conducted in a subtropical region) that causes severe injuries to the aerial part of plants and the pastures normally recover only in November/ December. Forage samples were collected in the morning, one day before grazing.

In each pasture, three rectangular quadrats of $1 \mathrm{~m}^{2}$ were placed at points that represented the average canopy condition of the pasture, and each sampling unit was vertically stratified into three parts (Table I). After collection, the samples were weighed, mixed with the other samples of the same stratum and subsampled. Fresh samples from each stratum were weighed on a 5-g accuracy scale. Three subsamples were separated from each stratum - one of the subsamples was used to assess the morphological composition, the second was used to estimate the herbage mass, and the third was used to assess the fatty acid profile and crude protein (CP) according to AOAC (2000).

The following morphological components were measured: stems (stems and pseudo-stems), leaves, and dead material. The samples were dried in forced-draught oven at $60^{\circ} \mathrm{C}$ for $72 \mathrm{~h}$ to determine the dry weight, proportions of leaves, stems and dead material and the fatty acid profile of 
each component. These data were used to estimate the leaf/stem ratio by dividing the proportion of leaf by the proportion of stem in each stratum.

The herbage dry matter content was estimated using microwave. The procedure used 100 to 150 g samples of forage cut into pieces of 3 to $5 \mathrm{~cm}$. These were evenly spread over a container, placed in the microwave along with a fresh glass of cold water (three-quarters full) in order to prevent ignition and fire, and dried on full power (high) during 3 to 5 minutes intervals. After every drying cycle, samples were weighed, turned, and spread out again to improve evenness of drying. When the sample started to look dry the drying interval was reduced to 0.5 to 1 minute. The drying process was considered complete when the sample weight did not change after two or three consecutive drying intervals. The dry matter content of the herbage was calculated as the ratio between the dry and the fresh weight of samples expressed in percentage. The estimated herbage mass values were used to calculate the stocking rate necessary to graze the pastures down to the desired residue targets. The occupation period was calculated to last two days based on a total herbage intake of $2.5 \%$ body weight. Lactating dairy cows (average body weight of $550 \mathrm{~kg}$ ) or dairy heifers (average body weight of $320 \mathrm{~kg}$ ) were used to graze down pastures, using the mob stocking method (Allen et al. 2011).

Fresh forage subsamples from strata 1 and 2, as well as the leaves, stems and dead material, were kept frozen (Arvidsson et al. 2009), and after the end of experiment were thawed, dried, and ground prior to the analysis of the FA profile. The samples from strata 1 and 2, were frozen (Arvidsson et al. 2009) until lipid extraction. Lipids were extracted from $3 \mathrm{~g}$ of sample by refluxing for $4 \mathrm{~h}$ with hexane by using a Soxhlet extraction apparatus according to AOAC methods 948.22 and 960.39 (AOAC 2000). After fat extraction the FA analysis was performed using gas chromatography at the Department of Chromatographic and Chemical
Assays located at the Agricultural Research and Rural Extension Corporation of the State of Santa Catarina (EPAGRI).

A $1.5-\mathrm{mL}$ aliquot of saponification solution (0.5 N KOH in methanol) was added to a threaded tube and placed in reaction blocks for 1 hour at $80^{\circ} \mathrm{C}$ for digestion. Next, $4.5 \mathrm{~mL}$ of acid methanol solution ( $\left.1 \mathrm{M} \mathrm{H}_{2} \mathrm{SO}_{4}\right)$ was added, and the tubes were again placed in the block for $1 \mathrm{~h}$ at $80^{\circ} \mathrm{C}$. After esterification, the samples were allowed to cool, and $2 \mathrm{~mL}$ of $\mathrm{n}$-hexane was added to extract the methyl esters from the fatty acids. Following agitation of the tubes using a vortex, approximately $1 \mathrm{~mL}$ of the n-hexane phase was transferred to a flask suitable for the automatic injector of the gas chromatograph.

The FA profile was determined using a Shimadzu 17A gas chromatograph (Shimadzu Europe company) equipped with a flame ionisation detector and a Supelco SP2340 capillary column (60 $\mathrm{mm} \times 0.25 \mathrm{~mm} \times 0.2 \mu \mathrm{m}$ ). The length of the column used in this study was sufficient to evaluate the main fatty acids in forage $(50 \mathrm{~mm}$ used by Arvidsson et al. 2009 and Witkowska et al. 2008). The detector and injector temperatures were $260^{\circ} \mathrm{C}$ and $140^{\circ} \mathrm{C}$, respectively. The initial temperature of the column was held to $120^{\circ} \mathrm{C}$ for $5 \mathrm{~min}$, and then it was progressively increased by $4^{\circ} \mathrm{C} \mathrm{min}^{-1}$ until it reached a final temperature of $240^{\circ} \mathrm{C}$, where it was held constant for $5 \mathrm{~min}$. The carrier gas $\left(\mathrm{H}_{2}\right)$ showed a linear velocity of $0.17 \mathrm{~m} \mathrm{~second}^{-1}$, which corresponded to the column flow rate of $0.67 \mathrm{~mL}$ $\min ^{-1}$. The injection volume was $1 \mu \mathrm{L}$ at a split ratio of 1:50; both the volume and split ratio were adequate for the sample size. The identification of the peaks was performed by comparing the retention time of the peaks to the standards for the methyl esters (Supelco 37 Component FAME Mix, 47885$\mathrm{U})$. Only cis fatty acids isomers were identified and the proportion of fatty acids was calculated by comparing the peak area of the methyl ester of 
interest to the total area of the identified peaks, and the values were presented as a percentage.

Data were analysed using the MIXED procedure (mixed models) of the SAS (Statistical Analysis System) software package, version 9.1 for Windows. The MIXED procedure was chosen based on the data collection methods (collected sequentially over time), and the covariance matrix was chosen using Akaike's Information Criterion (AIC). Grazing cycle was not included in the model, as it was considered to be a repeated measurement. Following variables were analysed: proportion of leaves, stem, dead material and leaf/stem ratio and fatty acids proportions. The model included the effect of pre-grazing height (90 and $120 \mathrm{~cm}$ ), levels of defoliation (50 and 70\% of initial height) and grazing stratum (1 and 2). Tukey's test was used to compare the means with a significance level of $5 \%$.

\section{RESULTS}

The highest proportions of leaves available to the animals were in stratum 1 of the pasture regardless of the treatment. The proportions of leaves and stems showed interactions with pre-grazing height, the level of defoliation and grazing stratum (Table II). The highest proportion of leaves was observed in stratum 1 of the 120/70 pastures. Stratum 2 of this treatment had the lowest proportion of leaves, which resulted in an average (stratum 1 and 2) of $55 \%$ of the leaves being available to the animals in the grazing stratum. The proportion of stems showed an opposite trend, as the highest values were obtained in stratum 2 of the 120/70 and 90/70 swards.

Regardless the treatment, the main FAs were C18:3, C18:2 and C16:0, which comprised approximately $94 \%$ of the total fatty acids (TFAs) and C18:3 showed the highest proportion in pasture (an average of 58\%). There was no interaction between the sward height and the level of defoliation (Table III). The pre-grazing heights modified the proportion of some FAs with the greatest proportions of C16:0 (19\%) found in pastures with $120 \mathrm{~cm}$ and the greatest proportions of $\mathrm{C} 18: 3$ (58\%) found in the $90 \mathrm{~cm}$ pastures. The largest differences in FA profiles were found between strata 1 and 2 (Table III). The higher percentages of C18:3 (63\%) and crude fat (3\%) were found in stratum 1 of the pasture, whereas higher proportions of C16:0 (20\%), C18:1 (2.8\%) and $\mathrm{C} 18: 2(21 \%)$ were found in stratum 2. Although the values of $\mathrm{C} 16: 0, \mathrm{C} 18: 1$ and $\mathrm{C} 18: 2$ were higher in stratum 2, C18:3 remained the predominant FA $(52 \%)$ in this portion.

We found higher proportions of $\mathrm{C} 18: 3$ in the leaves $(61 \%)$ compared with the stems $(18 \%)$ (Fig. 2). By contrast, higher proportions of $\mathrm{C} 18: 2$ and C16:0 were found in the stems (30 and $39 \%$ ) compared with the leaves (14 and 17\%) (Fig. 2). Moreover, no significant differences in the proportion of FAs were found between the expanding leaves and fully expanded leaves.

\section{DISCUSSION}

The milk and meat from animals with a pasturebased diet reportedly have a better nutritional quality due to increased PUFAs in these products, mainly omega-3 and CLA cis-9 trans-11 (Patel et al. 2013). This fact is directly associated with the high content of PUFA, mainly linolenic acid, in green forage (Dewhurst et al. 2006); studies with temperate forages have shown that some pasture management strategies can increase its concentrations in plants (Glasser et al. 2013, Witkowska et al. 2008).

In the current study, there was no interaction between sward height and level of defoliation and also there was no defoliation level effect on forage fatty acid profile among treatments. The highest proportions of $\mathrm{C} 18: 3$ and total lipids were related to the highest proportion of leaves found in stratum 1 and a pre-grazing height of $90 \mathrm{~cm}$. However, the highest proportions of $\mathrm{C} 16: 0$ and $\mathrm{C} 18: 2$ were found 
TABLE II

Pre-grazing proportion (\%) of leaves, stems, and dead material and leaf:stem ratios of elephant grass cv. Pioneiro subjected to different grazing heights and levels of defoliation.

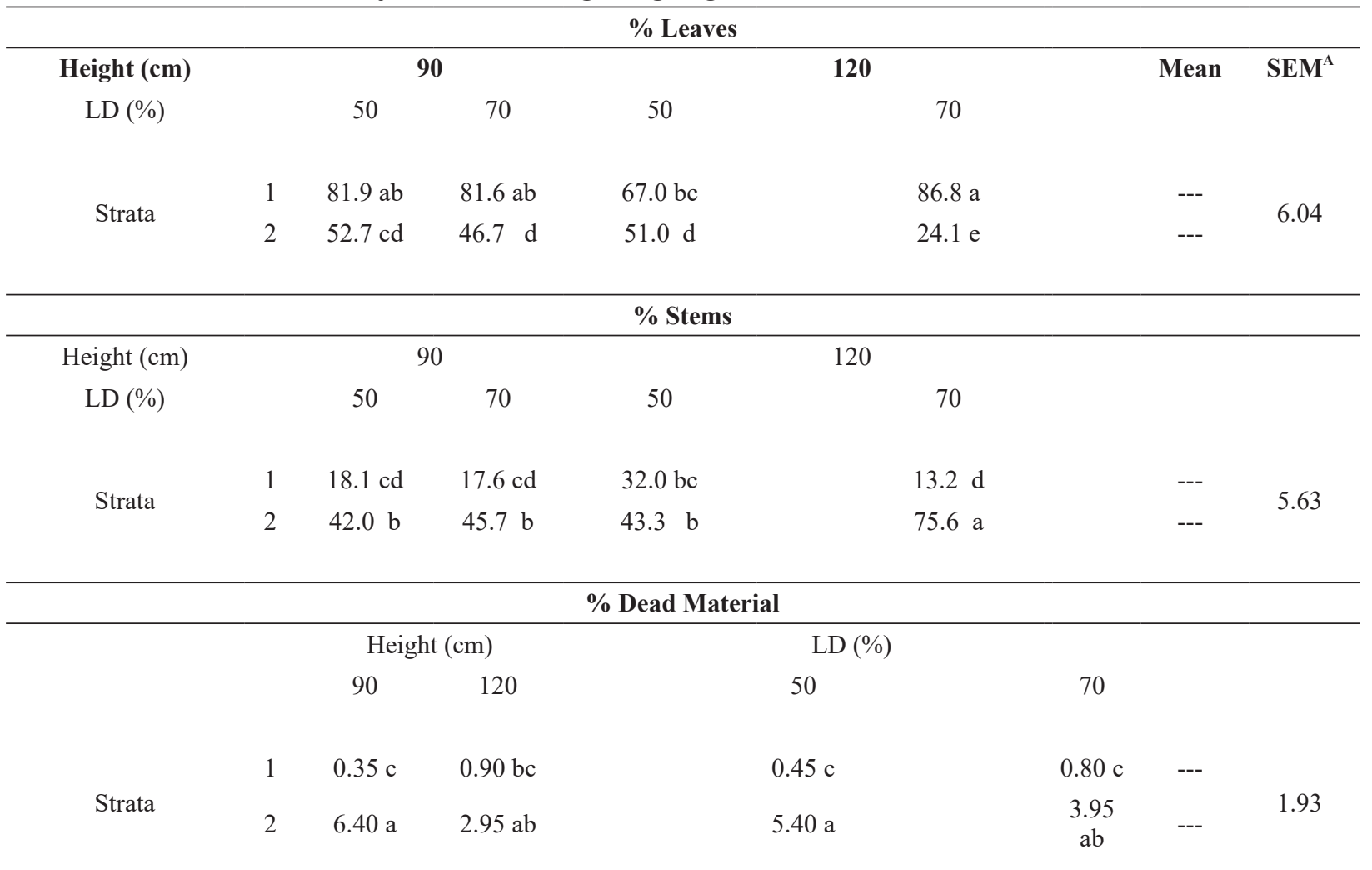

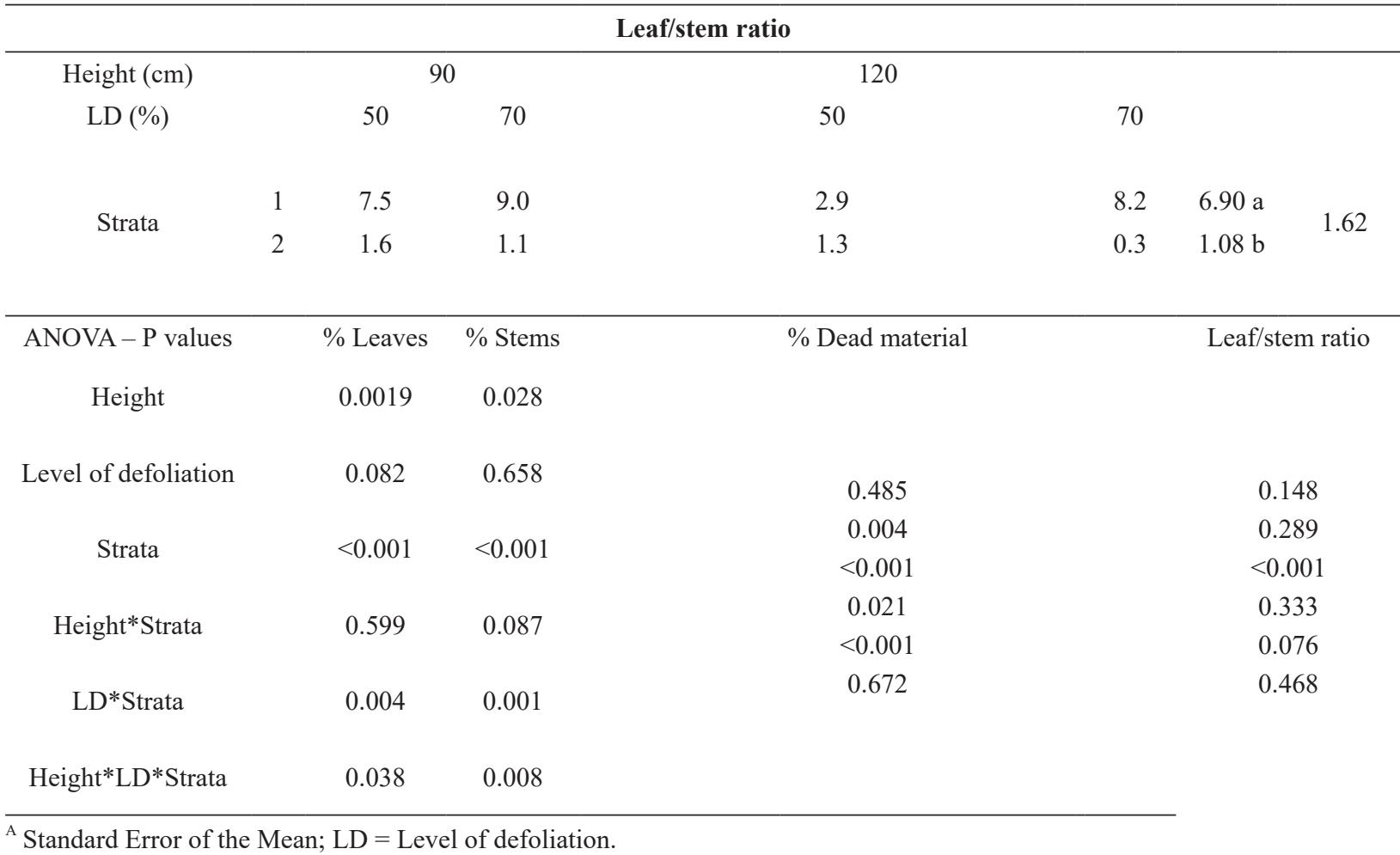


TABLE III

Concentrations of fatty acids (\% of observed fatty acids) and total lipids (TL \%) in elephant grass cv. Pioneiro subjected to different grazing heights and levels of defoliation.

\begin{tabular}{|c|c|c|c|c|c|c|c|c|}
\hline Height & $\mathbf{L D}^{\mathrm{B}}$ & Strata & \% C16:0 & \% C16:1 & \% C18:1 & \% C18:2 & \% C18:3 & TL \\
\hline \multirow{4}{*}{90} & \multirow{2}{*}{50} & 1 & 15.5 & 4.2 & 1.6 & 15.1 & 63.5 & 3.6 \\
\hline & & 2 & 19.1 & 3.6 & 3.1 & 20.0 & 53.8 & 2.5 \\
\hline & \multirow{2}{*}{70} & 1 & 15.5 & 4.1 & 1.7 & 14.1 & 64.7 & 3.1 \\
\hline & & 2 & 20 & 3.8 & 3.0 & 21.4 & 51.7 & 2.4 \\
\hline \multirow{4}{*}{120} & \multirow{2}{*}{50} & 1 & 20 & 4.1 & 1.5 & 15.4 & 61.5 & 3.1 \\
\hline & & 2 & 17.5 & 4.4 & 2.8 & 20.0 & 52.6 & 2.5 \\
\hline & \multirow{2}{*}{70} & 1 & 17 & 4.0 & 0.9 & 16.0 & 62.0 & 2.6 \\
\hline & & 2 & 21.5 & 4.0 & 2.7 & 23.0 & 48.7 & 1.9 \\
\hline & \multicolumn{2}{|c|}{$\mathrm{SEM}^{\mathrm{A}}$} & 0.349 & 0.128 & 0.178 & 0.429 & 0.779 & 0.130 \\
\hline & \multirow{2}{*}{ Strata } & 1 & $17.0 \mathrm{~b}$ & 4.1 & $1.4 \mathrm{~b}$ & $15.2 \mathrm{~b}$ & $62.9 \mathrm{a}$ & $3.1 \mathrm{a}$ \\
\hline & & 2 & $19.5 \mathrm{a}$ & 4.0 & $2.9 \mathrm{a}$ & $21.1 \mathrm{a}$ & $51.7 \mathrm{~b}$ & $2.3 \mathrm{~b}$ \\
\hline & \multirow{2}{*}{ Height } & $90 \mathrm{~cm}$ & $17.5 \mathrm{~b}$ & 3.9 & 2.4 & 17.7 & $58.4 \mathrm{a}$ & 2.9 \\
\hline & & $120 \mathrm{~cm}$ & $19.0 \mathrm{a}$ & 4.1 & 2.0 & 18.6 & $56.2 \mathrm{~b}$ & 2.5 \\
\hline & \multicolumn{2}{|c|}{ ANOVA - P Values } & $\% \mathrm{C} 16: 0$ & $\% \mathrm{C} 16: 1$ & \% C18:1 & \% C18:2 & \% C18:3 & $\mathrm{TL}$ \\
\hline & \multicolumn{2}{|c|}{ Height } & 0.004 & 0.328 & 0.146 & 0.138 & 0.051 & 0.113 \\
\hline & \multicolumn{2}{|c|}{ Strata } & $<0.001$ & 0.370 & $<0.001$ & $<0.001$ & $<0.001$ & $<0.001$ \\
\hline & \multicolumn{2}{|c|}{ Height*Strata } & 0.665 & 0.109 & 0.705 & 0.819 & 0.934 & 0.526 \\
\hline & \multicolumn{2}{|c|}{ LD*Strata } & 0.167 & 0.996 & 0.763 & 0.062 & 0.090 & 0.651 \\
\hline & \multicolumn{2}{|c|}{ Height*LD*Strata } & 0.684 & 0.407 & 0.494 & 0.988 & 0.797 & 0.497 \\
\hline
\end{tabular}

${ }^{\mathrm{A}}$ Standard Error of the Mean; ${ }^{\mathrm{B}}$ Level of defoliation.

in stratum 2 and in pre-grazing height of $120 \mathrm{~cm}$, which had the highest proportion of stems. This difference in the fatty acid profile among the strata can be explained by the fact that most of the lipids, particularly unsaturated fats, are present in the leaf chloroplast membrane (Arvidsson 2009).

In the present experiment, the higher proportions of leaves in the elephant grass grazing strata provided a higher proportion of $\mathrm{C} 18: 3$ (Fig. 3). Elgersma et al. (2005) and Dewhurst et al. (2001) also found a positive relationship between the proportion of leaves and the proportion of FAs, particularly C18:3. Conversely, Elgersma et al. (2003) did not report such a relationship between the proportion of FAs and the proportion of leaves. These authors, who worked with Lolium perenne L. in the Netherlands, found that the relationship between the proportion of leaves and C18:3 may be more important in certain seasons (early summer) than other factors, such as light intensity and temperature in late summer when the proportion of leaves is high. 


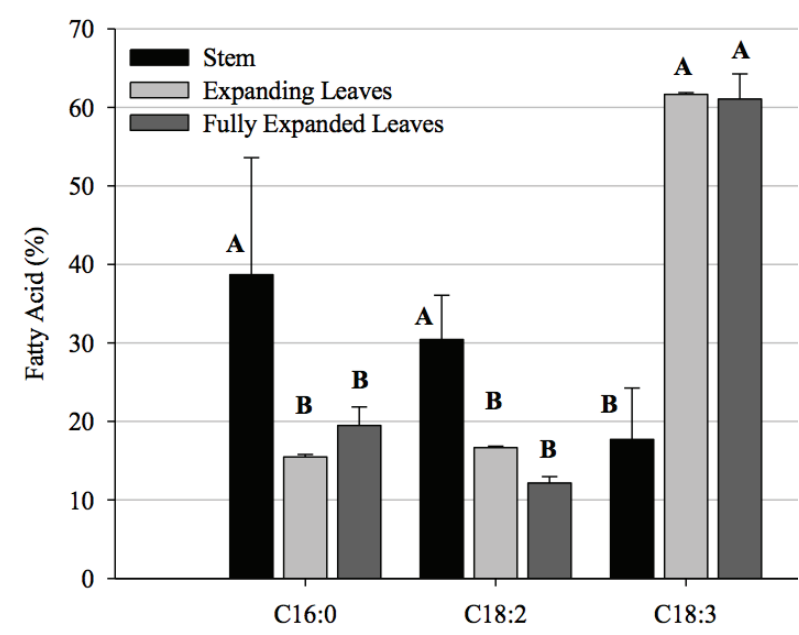

Figure 2 - Fatty acid profile observed in stems, expanding leaves, and fully expanded leaves of Pioneiro elephant grass. Within a specific fatty acid, the means for plant parts are different $(\mathrm{P}<0.05)$ if the letters above the histogram differ.

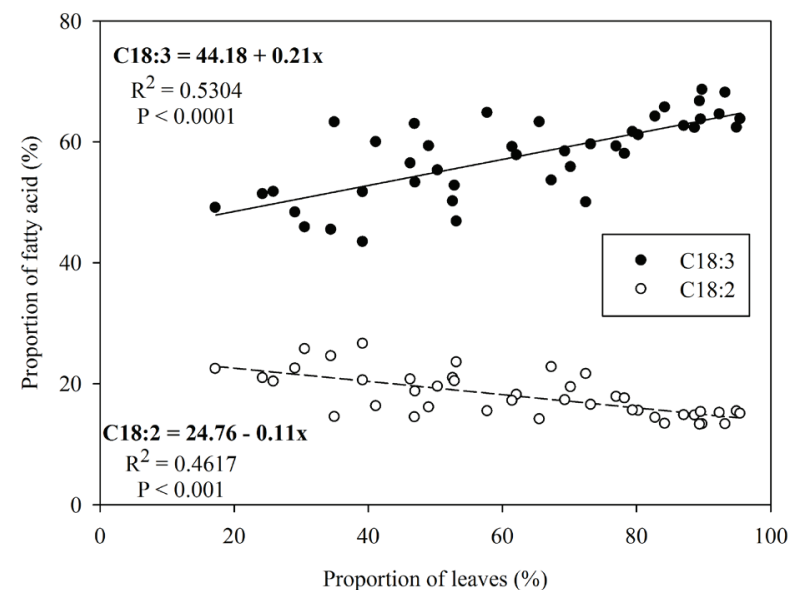

Figure 3 - Relationship between the proportion of leaves and the concentration of linolenic (C18:3) and linoleic (C18:2) acids in elephant grass subjected to intermittent stocking.

Many of the published studies regarding fatty acid profiles in forage were conducted with temperate climate plants. However, the good relationship between leaf proportion and $\mathrm{C} 18: 3$ observed in this study (Fig. 3) shows that grazing management strategies that increase pasture leaf/stem ratio could provide a better fatty acid profile even in a tall tufted tropical plant such as elephant grass. In the current study, the proportion of leaves was lower than that found by Santos et al. (2003) for the same cultivar (81\%) and higher than that observed for the dwarf elephant grass cultivar (45\%) (Crestani et al. 2013). At a similar level of defoliation (70\%), Botrel et al. (2000) reported a lower leaf/stem ratio for the Pioneiro and Cameroon cultivars (1.5 and 2.2, respectively) than that found in the present study (3.7). There was a marked difference in the proportion of leaves between the strata in the $120 / 70$ pastures; stratum 1 corresponded to the upper $42 \mathrm{~cm}$ of the canopy (Table I) from which the highest proportion of leaves was obtained (Table II). Consequently, stratum 2 was notable for a higher proportion of stems, and the same trend was observed in the 90/70 pastures (Table II). Thus, despite the fact that stratum 1 of the 90/50 treatment had a lower proportion of leaves than the 120/70 paddocks, the proportion of leaves available to the animals in the grazing stratum of the $90 / 50$ paddocks was higher than in the $120 / 70$ treatment (67\% vs. $55 \%$, respectively).

The lack of difference $(\mathrm{P}>0.05)$ in the FA profile among the levels of defoliation can be explained by the similar proportion of leaves in the grazing strata (average of stratum 1 and 2) of the $90 / 50$ and $90 / 70$ (67\% and $64 \%$, respectively) treatments and the 120/50 and 120/70 treatments (59\% and 55\%). Although the proportions of FAs, particularly C18:3, were similar between the levels of grazing severity tested, the treatments with $70 \%$ severity should not be recommended because the post-grazing heights of these treatments were not effectively reached by the grazing animals (Rodolfo et al. 2015). This difficulty in grazing down to very low stubble heights was also reported in an experiment using a similar experimental protocol with Pennisetum purpureum cv. Napier (Pereira et al. 2014). This outcome was due to a higher presence of stems following the $50 \%$ reduction of the initial pasture height, which resulted in a barrier 
to further defoliation (Zanini et al. 2012, Fonseca et al. 2012) and a lower amount of residual leaves.

The synthesis of PUFAs plays an important role in the adaptation and survival of plants in cold temperatures, as it contributes to the maintenance of membrane fluidity in the chloroplast (Uemura et al. 1995). Therefore, PUFAs are present in higher amounts in plants in temperate climates (Hugly and Somerville 1992). In this study, C18:3 was the major FA present in the pasture, which varied from 48.7 to $64.7 \%$ of the observed TFAs, and these values were lower than those found in mixed temperate forage in Switzerland (59 to 73\%) (Wyss et al. 2010) and higher than those found in tropical pastures in Australia (12.8 to 36.2\%) (O'Kelly and Reich 1976) and Brazil (20.8 to 45.6\%) (Fernandes 2004). The different proportions of $\mathrm{C} 18: 3$ found in the studies of tropical forage can be explained by the methods used for collecting the forage and/or by climate differences. In this study, the collection of forage varied from 50 to $70 \%$ of the pre-grazing height, and the plants were grown in a subtropical climate with average and minimum temperatures ranging from 20 to $10^{\circ} \mathrm{C}$ and from 14 to $-3.4^{\circ} \mathrm{C}$ in January and June, respectively (Fig. 1). In the studies conducted in Australia (O'Kelly and Reich 1976) and Brazil (Fernandes, 2004), the collection of forage was performed at an average of $66 \%$ of the pre-grazing height and the temperatures were higher, ranging from 22 to $32^{\circ} \mathrm{C}$ and from 23 to $25^{\circ} \mathrm{C}$, respectively. One explanation for the higher proportions of PUFAs found in the elephant grass cv. Pioneiro in locations with lower temperatures may be the influence of temperature on the activation of the desaturase enzymes responsible for inserting double bonds into FAs, a process that favours photosynthesis and promotes cold tolerance (Routaboul et al. 2012, Iba 2002).

However, the higher PUFAs found in this study were related with morphological composition and crude protein content of pasture. Comparing with $\mathrm{NDF}$ and ADF, the crude protein was the predictor most closely related with FA content in this study. Linear functions of CP were observed with C18:3 (positive), C18:2 and C16:0 (negative) (Fig. 4). Similar results were observed in a meta-analysis published by Glasser et al. (2013) but, probably because the higher variability of data, the content of $\mathrm{C} 18: 2$ and $\mathrm{C} 18: 3$ were quadrat functions of $\mathrm{CP}$. The presence of a higher proportion of $\mathrm{C} 18: 3$ in pastures with the greatest proportion of leaves (Fig. 3 ) and crude protein content (Fig. 4a), i.e., stratum 1 or pastures grazed at an initial height of $90 \mathrm{~cm}$, can be partially explained by the higher proportions of this FA in leaves rather than in stems (Fig. 2). By contrast, the greatest proportions of $\mathrm{C} 18: 2$ and C16:0 in pastures with the lowest proportions of leaves and crude protein (Fig. 4b), as in stratum 2 or for a height of $120 \mathrm{~cm}$ (Table III), can be explained by the higher proportions of $\mathrm{C} 18: 2$ and $\mathrm{C} 16: 0$ in stems rather than in leaves (Fig. 2). The same trend was observed by Vlaeminck et al. (2010) in studies with Lolium perenne L. managed under a rotational system where the proportion of C18:2 increased linearly, whereas C18:3 declined throughout the 4-day of grazing and was accompanied by an increase in the amount of stems (Vlaeminck et al. 2010). Thus, the higher proportions of leaves in the pasture, regardless of their stage of development, resulted in higher percentages of $\mathrm{C} 18: 3$.

In conclusion, the $90 / 50$ grazing stratum treatment appears to be the most appropriate if the goal is to provide pasture with the highest proportion of linolenic acid for grazing animals. Differences in linolenic acid proportions between strata suggest that some grazing management strategies, such as first-last stocking, could provide even higher amounts of this fatty acid to lactating cows. The management techniques used in this study provided a higher proportion of fat and C18:3 compared with other techniques used for the same species and other tropical forages. 

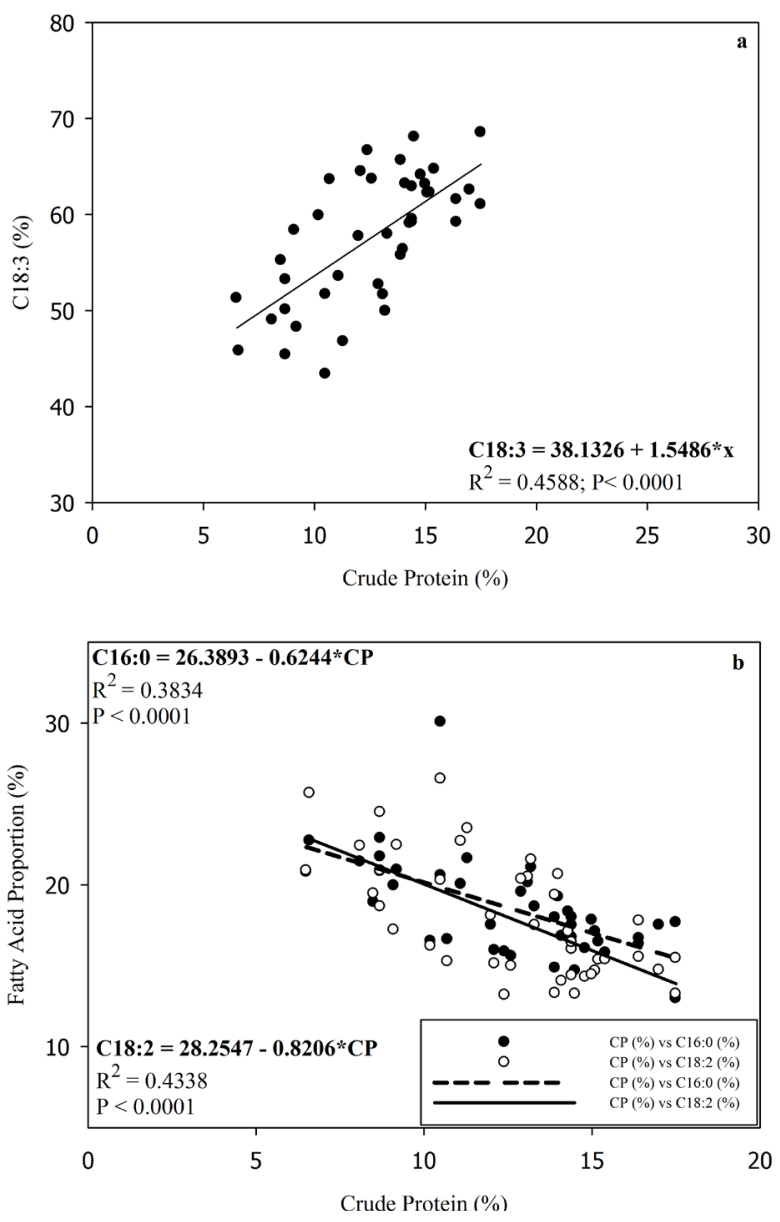

Figure 4 - Relationship between crude protein content and linolenic (C18:3; a), linoleic (C18:2; b) and palmitic (C16:0; b) acids in elephant grass subjected to intermittent stocking.

\section{ACKNOWLEDGMENTS}

All authors state that there are no financial and personal conflicts of interest that could have inappropriately influenced their work. The authors would like to thank Coordenação de Aperfeiçomento de Pessoal de Nível Superior (CAPES) for financial support through the scholarship, (Conselho Nacional de Desenvolvimento Científico e Tecnológico) (CNPq) and Fundação de Amparo à Pesquisa e Inovação do Estado de Santa Catarina (FAPESC) for funding this research (Grant numbers 483533/2011-4 and 2015 TR-384, respectively) and the Departamento de Produção e
Alimentação Animal of Universidade do Estado de Santa Catarina (UDESC) for granting access to the site and the animals used for the experiment.

\section{REFERENCES}

ALLEN VG ET AL. 2011. An international terminology for grazing lands and grazing animals. Grass Forage Sci 66: $2-28$.

AOAC - ASSOCIATION OF OFFICIAL ANALYTICAL CHEMISTS. 2000. Association of Analitical Chemist. Official methods of the Association of the Analytical Chemists. 17th ed., AOAC, Washington, USA, method 925. 38

ARVIDSSON K. 2009. Factors affecting fatty acid composition in forage and milk. Ph.D. Thesis. Swedish University of Agricultural Sciences, Swedish.

ARVIDSSON K, GUSTAVSSON AM AND MARTINSSON K. 2009. Fatty acids in forages: a comparison of different pre-treatments prior to analysis. Anim Feed Sci Technol 151: 143-152.

BARTHRAM GT. 1985. Experimental techniques: the HFRO sward stick. In: The Hill Farming Research Organization Biennial Report 1984/1985, p. 29-30. Penicuik: HFRO.

BAUMAN DE, BAUMGARD LH, CORL BA AND GRIINARI JM. 2000. Biosynthesis of conjugated linoleic acid in ruminants. J Anim Sci 77: 1-15.

BOTREL MA, PEREIRA AV, FREITAS VP AND XAVIER DF. 2000. Potencial forrageiro de novos clones de capimelefante. Rev Bras Zootec 29: 334-340.

BOUFAÏED H, CHOUINARD PY, TREMBLAY GF, PETIT HV, MICHAUD R AND BÉLANGER G. 2003. Fatty acids in forages. I Factors affecting concentrations. Can J Anim Sci 3: 501-511.

CLAPHAM WM, FOSTER JG, NEEL JPS AND FEDDERS JM. 2005. Fatty acid composition of traditional and novel forages. J Agric Food Chem 53: 10068-10073.

CRESTANI S, RIBEIRO FILHO HMN, MIGUEL MF, ALMEIDA EX AND SANTOS FAP. 2013. Steers performance in dwarf elephant grass pastures alone or mixed with Arachis pintoi. Trop Anim Health Prod 45: 1369-1374.

DALEY CA, ABBOTT A, DOYLE PS, NADER GA AND LARSON S. 2010. A review of fatty acid profiles and antioxidant content in grass-fed and grain-fed beef. Nutr J 9: 1-12.

DEMEYER D AND DOREAU M. 1999. Targets and procedures for altering ruminant meat and milk lipids. Proc Nutr Soc 58: 593-607.

DEWHURST RJ, SCOLLAN ND, YOUELL SJ, TWEED JKS AND HUMPHREYS MO. 2001. Influence of species, cutting date and cutting interval on the fatty acid composition of grasses. Grass Forage Sci 56: 68-74. 
DEWHURST RJ, SHINGFIELD KJ, LEE MRF AND SCOLLAN ND. 2006. Increasing the concentrations of beneficial polyunsaturated fatty acids in milk produced by dairy cows in high-forage systems. Anim Feed Sci Technol 131: 168-206.

DIERKING RM, KALLENBACH RL AND GRÜN IU. 2010. Effect of forage species on fatty acid content and performance of pasture-finished steers. Meat Sci 85: 597605.

ELGERSMA A, ELLEN G, VAN DER HORST H, MUUSE BG, BOER H AND TAMMINGA S. 2003. Comparison of the fatty acid composition of fresh and ensiled perennial ryegrass (Lolium perenne L.), affected by cultivar and regrowth interval. Anim Feed Sci Technol 108: 191-205.

ELGERSMA A, MAUDET P, WITKOWSKA IM AND WEVER AC. 2005. Effects of nitrogen fertilisation and regrowth period on fatty acid concentrations in perennial ryegrass (Lolium perenne L.) Ann Appl Biol 147: 145-152.

EPAGRI. 2012. Eletronic publication [personal message]. Message received by $<$ sbrissia@cav.udesc.br $>$ on $30^{\text {th }}$ July, 2012.

FERNANDES SAA. 2004. Levantamento exploratório da produção, composição e perfil de ácidos graxos do leite de búfalas em cinco fazendas do estado de São Paulo. Ph.D. Thesis, Universidade de São Paulo, São Paulo.

FONSECA L, MEZZALIRA JC, BREMM C, FILHO RSA, GONDA HL AND CARVALHO PC DE F. 2012. Management targets for maximising the short-term herbage intake rate of cattle grazing in Sorghum bicolor. Livest Sci 145: 205-211.

GLASSER F, DOREAU M, MAXIN G AND BAUMONT R. 2013. Fat and fatty acid content and composition of forages: A meta-analysis. Anim Feed Sci Technol 185: 19-34.

HUGLY S AND SOMERVILLE C. 1992. A role for membrane lipid polyunsaturation in chloroplast biogenesis at low temperature. Plant Physiol 99: 197-202.

IBAK. 2002. Acclimative response to temperature stress in higher plants: approaches of gene engineering for temperature tolerance. Annu Rev Plant Biology 53: 225-245.

LOCK AL AND GARNSWORTHY PC. 2002. Independent effects of dietary linoleic and linolenic fatty acids on the conjugated linoleic acid content of cows milk. Anim Sci 74: 163-176.

MCGUIRE MA AND MCGUIRE MK. 2000. Conjugated linoleic acid (CLA): A ruminant fatty acid with beneficial effects on human health. J Anim Sci 77: 1-8.

O'KEEFFE M AND ST-ONGE M. 2013. Saturated fat and cardiovascular disease: A review of current evidence. Curr Cardio Risk Rep 7: 154-162.

O'KELLY JC AND REICH HP. 1976. The fatty acid composition of tropical pastures. J Agric Sci 86: 427-429.

PALLADINO RA, O'DONOVAN M, KENNEDY E, MURPHY JJ, BOLAND TM AND KENNY DA. 2009.
Fatty acid composition and nutritive value of twelve cultivars of perennial ryegrass. Grass Forage Sci 64: 219226.

PATEL M, WREDLE E AND BERTILSSON J. 2013. Effect of dietary proportion of grass silage on milk fat with emphasis on odd- and branched-chain fatty acids in dairy cows. J Dairy Sci 96: 390-397.

PEREIRA LET, PAIVA AJ, GEREMIA EV AND DA SILVA SC. 2014. Components of herbage accumulation in elephant grass cvar Napier subjected to strategies of intermittent stocking management. J Agric Sci 152: 954966.

PUTNAM J, ALLSHOUSE J AND KANTOR LS. 2002. U.S. Per Capita Food Supply Trends: More Calories, Refined Carbohydrates, and Fats. Food Rev 25: 2-15.

REVELLO CA, TABACCO E, GIACCONE D, PEIRETTI PG, BATTELLI G AND BORREANI G. 2010. Variation of fatty acid and terpene profiles in mountain milk and "Toma piemontese" cheese as affected by diet composition in different seasons. Food Chem 121: 393-399.

RODOLFO GR, DIAS KM, SCHMITT D AND SBRISSIA AF. 2015. Levels of defoliation and regrowth dynamics in elephant grass swards. Cien Rural 45: 1299-1304.

ROUTABOUL J, SKIDMORE C, WALLIS JG AND BROWSE J. 2012. Arabidopsis mutants reveal that shortand long-term thermotolerance have different requirements for trienoic fatty acids. J Exp Bot 63: 1435-1443.

SANTOS MVF, DUBEUX JR JCB, SILVA MC, SANTOS SF, FERREIRA RLC, MELLO ACL, FARIAS I AND FREITAS EV. 2003. Produtividade e composição química de gramíneas tropicais na Zona da Mata de Pernambuco. Rev Bras Zootec 32: 821-827.

THOMAS H. 1986. The role of polyunsaturated fatty acids in senescence. J Plant Physiol 123: 97-105.

UEMURA M, JOSEPH RA AND STEPONKUS PL. 1995. Cold acclimation of Arabidopsis thaliana. Plant Physiol 109: 15-30.

VLAEMINCK B, ABRAHAMSE PA, FIEVEZ V, LOURENCO M, DIJKSTRA J AND TAMMINGA S. 2010. The effect of allocation frequency in rotational grazing systems on the fatty acid profile in milk fat of dairy cows. In: Grassland in a changing world. 23th General Meeting of the European Grassland Federation. p. 102. Germany, August 29-September 2.

VOLTOLINI TV, SANTOS FAP, MARTINEZ JC, IMAIZUMI H, CLARINDO RL AND PENATI MA. 2010. Produção e composição do leite de vacas mantidas em pastagens de capim-elefante submetidas a duas frequências de pastejo. Rev Bras Zootec 39: 121-127.

WITKOWSKA IM, WEVER C, GORT G AND ELGERSMA A. 2008. Effects of Nitrogen Rate and Regrowth Interval on Perennial Ryegrass Fatty Acid Content during the Growing Season. Agron J 100: 1371-1379. 
WYSS U, MÜNGER A AND COLLOMB M. 2010. Variation of fatty acid in grass and milk during the grazing season. In: Grassland in a changing world. 23th General Meeting of the European Grassland Federation. p. 422-425. Germany, August 29-September 2.
ZANINI GD, SANTOS GT, SCHMITT D, PADILHA DA AND SBRISSIA AF. 2012. Distribuição de colmo na estrutura vertical de pastos de capim-aruana e azevém anual submetidos à pastejo intermitente por ovinos. Cien Rural 42: 882-887. 